\title{
Analysis of the state of formation of future teacher's communicative competence as a condition of providing the quality of general secondary education
}

\author{
Iryna Trubavina ${ }^{1, *}$, Svitlana Vasylieva $^{1}$, and Anna Martyniuk $^{2}$ \\ ${ }^{1}$ H. S. Skovoroda Kharkiv National Pedagogical University, Department of General Pedagogy and Pedagogy of Higher School, \\ Kharkiv, 61102, Ukraine \\ ${ }^{2}$ H. S. Skovoroda Kharkiv National Pedagogical University, Department of English language, Kharkiv, 61102, Ukraine
}

\begin{abstract}
The scientific novelty of the article is that the authors have revealed the average level of the state of formation of communicative competence (CC) of the third-year students. The cognitive and emotional components dominate among all $\mathrm{CC}$ components (it can be observed among students of the Faculty of Natural Sciences, Faculty of Arts). The behavioral component of the CC is better formed among students of the Faculty of Foreign Philology and the Faculty of Arts and Graphics. The communicative tolerance prevails among students of the Faculty of Physical Education as well as the Faculty of Arts and Graphics. Moreover, the two factors influencing CC were revealed: the external factors (organization of students' subject leisure; professional-oriented educational work with students; content of education at institutions of higher pedagogical education: specialty of the chosen profession, increased cycle of humanities and psychological and pedagogical disciplines, active pedagogical practice of students; age of students to work with, different categories of children and adults to communicate with, pedagogical skills and $\mathrm{CC}$ of teachers); the internal factors (students' attitude towards self-development, self-education, students' life and social experience, motivation for acquiring a specialty and $\mathrm{CC}$, humanistic orientation of future teacher's personality, persona's orientation to "person to person" profession).
\end{abstract}

\section{Introduction}

Nowadays, the ideas of the New Ukrainian School are being implemented in Ukraine as well as the requirements for the quality of education are increasing and changing, including the requirements for teacher's education, both in the context of European integration and in the context of the Millennium Development Goals. According to the executive order No 776 of the Ministry of Education and Science of Ukraine dated July 16, 2018, "The Concept of pedagogical education development" was approved. It is stated in the concept that today there is a problem of imbalance "between the public demand for highly qualified teaching staff, the prospects for the development of society, global technological changes and the existing system of pedagogical education, as well as the level of readiness, ability of teaching staff to understand and implement the educational reforms in Ukraine"[1].

The quality of education is directly related to the teacher's willingness to work in the new environment. That is why the certification of teachers is offered today, and the opportunities for improving their qualification are being expanded. Nowadays, there is a rapid increase in the amount of information available to children. Teachers and books are not the only sources of knowledge today. The information that children get from the Internet is diverse, contradictory, and it can be threatening and provocative. It is easy to find the necessary material, samples of solving the problem, to gather the necessary material for training, and to make own solutions to the problem and form the necessary competencies on this basis. The teacher is a consultant, an assistant, a guide in acquisition of new material, a facilitator, even a mediator, but not a lecturer and not a translator of knowledge. This requires from a teacher to communicate with a student as a subject of education. This statement is also emphasized by in Law of Ukraine on "On General Secondary Education", according to which students, parents and teaching staff are equal participants in the educational process. Therefore all above mentioned requires teachers' high-level communicative competence (CC) in order to communicate and organize training and education in new roles as well as to organize learning process with students and their parents as equal participants. This brings communicative competence to the level of the educational process condition at the general secondary educational establishments, considering that communication permeates all kinds of human activity and at the same time is a separate kind of activity. It

\footnotetext{
* Corresponding author: trubavina@gmail.com
} 
should be noted that competencies are the result of studying at a higher educational establishment; in the Law of Ukraine "On Higher Education" (in the context of competency approach), they are considered to be "a dynamic combination of knowledge, skills and practical know-how; ways of thinking; professional, world-view and civic qualities; moral and ethical values, which determines the ability of a person to perform successfully professional and further educational activities and it is the result of education at a certain level of higher education" [2].

V. Kremen distinguishes the following types of competences: key (general) competences (intersubject and super-subject). They are defined as "the ability of a person to perform complex multifunctional, polysubject, cultural-purposeful activities, to solve effectively actual individual, social, and other problems" [3, pp. 9-17]. Communicative competences are general (key) competences, which are necessary for all future professionals due to the presence of it in all communication activities, but for the teacher they are also professional (special competencies), as the word is the main teacher's work tool. That means that the communication of a teacher with the students belongs to the intersubject and super-subject and at the same time to the professional competences, which proves the importance of formation of teacher's communicative competence in the aspect of improving the quality of general secondary education. This confirms that scientific and teaching staff in the educational process at higher pedagogical educational establishments should pay attention to the formation of future teachers' communicative competence.

The analysis of the recent researches has proved that the problem of introducing a new competency approach for higher education in Ukraine as well as the formation of teachers' communicative competence are the subject of modern pedagogical theory [4]. Thus, Yu. Tatur considers the competence to be an integral feature of a person and it characterizes his desire and ability (readiness) to realize his potential (knowledge, ability, experience, personal qualities, etc.) for successful activity in a certain field [5, p. 6-7].

O. Tsymbalyuk colligates competence with the ability of a person to perform professional functions. They include educational, upbringing and developmental functions, and the formation of pedagogical communication, communicative abilities and communicative skills is at the core of each [6, p. 8].

O. Kasatkina considers communicative competence to be the high-quality integral psychological quality, which is formed on the basis of a combination of communicative skills and empathy [7, p. 4-5]. D. Hodlevska adds communicative knowledge, speech skills, demonstration of reflection and creativity to the definition [8, p. 17-18].

I. Romanov notes that communicative competence is "the individual ability of a person to organize his speech activity adequately according to different situations of communication (by purpose, by role, by form, by content, etc.) in its productive and receptive types appropriate to each specific situation by linguistic means and methods" [9, 46-49].

I. Zymniaia defines that communicative abilities are person's individual and psychological features of a person, which ensure effective interaction and adequate mutual understanding between people in the process of communication or performing cooperation activities [10, p. 35-38]. The author emphasizes that communication skills allow a person to interact successfully with other people, to carry out communicative, organizational, pedagogical and other activities, to determine the qualitative and quantitative characteristics of the information exchange; to perceive and understand other people, to develop interaction strategies. S. Bucharskaya marks that communicative competence is a learning goal, "formed ability of a person to act as a subject of communicative activity, but communication in a foreign language can be taught. So, communicative competence as an ability only can be formed, developed and diagnosed" [11].

Therefore, nowadays, communicative competence of a teacher is his ability to communicate effectively with the students in subject-subject positions by creating a variety of conditions for them to learn new things. Its structure consists of knowledge in communication, pedagogical communication, communication skills, speech skills, communicative abilities, specific qualities and personality traits (empathy, reflection, creativity). That is why, the formation of future teacher's communicative competence is a long process, which is provided by different disciplines in the higher pedagogical educational establishments. So, the identification of the effectiveness of formation of future teacher's communicative competence is necessary, taking into account the results of teacher training for the analysis and correction in case of need.

Consequently, the purpose of the article is to determine the state of formation of future teachers' communicative competence at higher pedagogical educational establishments as well as to analyze the problems of formation of it. The tasks of the article are: to determine the state of formation of students' communication competence at higher pedagogical educational establishments and to identify the factors that influence the level of formation of students' communicative competence at higher pedagogical educational establishments.

\section{Methodology}

The theoretical analysis of the sources on the problem of formation of teacher's communicative competence, the analysis of documentation of higher pedagogical educational establishments, questioning (oral and written) of students and teaching staff, method of determining communicative competence by I. A. Martianova were used for the research [12]. It should be noted that today there are many methods for determining the communicative competence of future teachers; they are developed and substantiated by different scientists.

We have chosen the substantiated method of I. A. Martianova because it allows us to define several criteria for each component of communicative 
competence, which gives us a better understanding of the level of formation of communication competence through its components. It should be noted that this method is developed to determine the communicative preparedness of students of higher educational establishments. Other methods are dedicated to communicative competence of children of different ages, professionals from different fields, etc.

I. A. Martianova considers that the communicative competence is an effective tool for graduates' socialization and their adaptation in the modern multicultural society [12]. The communicative competence is considered in foreign researches as a student's ability to properly understand and use language to communicate in an authentic (rather than imitated) social and school environment [13]. At the same time, most scholars now consider linguistic competence as a part of communicative competence $[4 ; 13]$. Thus, Paulston believes that due to the communicative methodology of language initiation, the interest in learning language competence has expanded in order to include communicative competence [14]. That means, that the communicative competence in foreign studies is considered as a result of linguistic competence (while learning a foreign language) and as its component. We are interested in the teacher's communicative competence in the context of teacher's pedagogical communication and performing professional tasks that are mostly unrelated to foreign language learning.

In addition, the validity and reliability of diagnostics was verified by its author by an expert survey. This technique is a variant of self-diagnosis of students' communicative competence through a personal questionnaire based on closed questions, including a five-point rating scale of measurement [14]. These aspects led to the choice of this methodology for our study.

That is more important for the pedagogical activity results as well as for successful pedagogical communication among all the educational subjects. We are mostly impressed by the structure of the communicative competence, which I. A. Martianova offered to students: cognitive, behavioral communicative competence, communicative tolerance [12]. For pedagogical activity it is important for the teacher to know about effective communication, to be able to communicate with different children, their parents, colleagues, as well as to show tolerance to them, because all of them are different, moreover, it is important to work with all of them and qualitatively, in different directions.

Therefore, in our study, a simplified figure 1 illustrating the structure of the communicative competence can be used to identify the state of communicative competence formation of future teachers.

The basis for our research is: the legal framework and state documents for specialists' training at the current stage of development of national education, the concept of the New Ukrainian School, Laws of Ukraine "On Education", "On Higher Education", a competence approach to higher education, the regulations on communication as the main form of human activity, the theories of pedagogical communication and art of teaching.

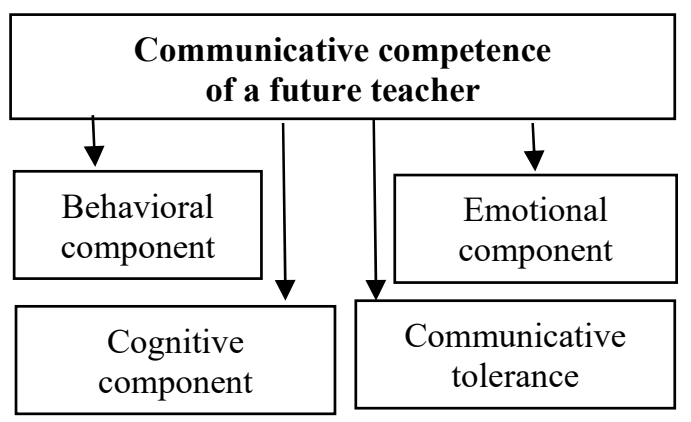

Fig. 1. Components of future teacher communicative competence

In order to conduct valid research dedicated to the determination of the level of communication competence, we chose students and took into account the current documents on the qualification levels of education. The National Qualifications System is developed in Ukraine in accordance with the European Qualifications System, it is a framework scheme that provides information on the generalized structure at all levels of qualifications of education. According to the law of Ukraine No776 "On Higher Education" dated July 16, 2018 qualification is considered to be "the official result of assessment and recognition obtained, when an authorized institution established that a person has attained competencies (education results) in accordance with higher education standards, which is certified by the relevant higher education document" [2]. We conducted our survey in third-year students of the first bachelor's level. According to the Law of Ukraine "On Higher Education", this level corresponds to the seventh level of the National Framework of Qualifications and identifies person's assimilation of theoretical knowledge and practical skills sufficient for successful fulfillment of professional duties in the chosen specialty [2]. We chose the third-year students, because the fourth-year students would have another year for correction the obtained results. After the third year of studying. many students work as teachers, that is why we consider that during the first three years of education teacher's communicative competence is formed at higher pedagogical educational establishments. Most of the theoretical subjects in general and professional training cycles (102 weeks from 132 weeks for pedagogical specialties), as well as a part of practical training (continuous propaedeutic pedagogical practice and pedagogical practice in general and specialized secondary educational establishments), which train future teachers for work in secondary educational establishments, are already taught, and only a part of theoretical preparation (30 weeks from 132 weeks of the budget time for pedagogical specialties) and practical training (pedagogical practice in general and special secondary educational establishments) remain unacquired by students.

The students of H. S. Skovoroda Kharkiv National Pedagogical University were interviewed in 2019 at the 
end of their third year, according to the method of I. A. Martianova [12]. The total amount of the interviewed students was 534. Among them there were 78 students of the Faculty of Foreign Philology, 76 students of the Faculty of Physical Education, 72 students of the Faculty of Natural Sciences, 74 students of the Faculty of Physics and Mathematics, 73 students of the Faculty of Arts and Graphics and the Faculty of Art, 80 students of the Primary Education Faculty, 81 students of the Psychology and Sociology Faculty. It should be mentioned that we conducted conversations with 20 teachers of each faculty. The total amount of the interviewed was 554, from the mentioned faculties of H. S. Skovoroda Kharkiv National Pedagogical University. The chosen specialties are related to naturalmathematical, artistic, humanitarian field, physical education and sports. The students were offered to answer 50 questions that consisted of four main scales: 1-10 - questions of the cognitive nature; 11-20 questions which determine emotional parameters of communicative competence; 21-40 - questions which reflect the behavioral component of communicative competence; 41-50 - questions which reflect the level of communicative tolerance. The questionnaires fitted a five-point rank scale, and the questions were of closed type. The first half of the questions reflects the positive characteristics of communication, the second part - the negative characteristics.

According to the received answers, an individual score was calculated according to Table 1.

Table 1. Individual score calculations.

\begin{tabular}{|c|c|c|c|c|c|}
\hline \multirow{2}{*}{$\begin{array}{c}\text { Question } \\
\text { numbers }\end{array}$} & \multicolumn{5}{|c|}{ Options for ratings } \\
\cline { 2 - 6 } & $\begin{array}{c}\text { almost } \\
\text { always }\end{array}$ & $\begin{array}{c}\text { in most } \\
\text { cases }\end{array}$ & $\begin{array}{c}\text { Some- } \\
\text { times }\end{array}$ & rarely & $\begin{array}{c}\text { almost } \\
\text { never }\end{array}$ \\
\hline $\begin{array}{c}\text { From } \\
1 \text { to 5 }\end{array}$ & & & & & \\
$11-15$ & 5 & 4 & 3 & 2 & 1 \\
$21-30$ & & & & & \\
$41-45$ & & & & & \\
\hline $\begin{array}{c}\text { From } \\
6 \text { to } 10\end{array}$ & & & 3 & 4 & 5 \\
$16-20$ & 1 & 2 & & & \\
$31-40$ & & & & & \\
$46-50$ & & & &
\end{tabular}

The results had a direct correlance: the higher the score was, the higher the level of communicative competence was. So, 220 and above points meant the high level; points from 180 to 220 certified the medium level with a tendency to the high level; points from 140 to 180 meant the average level; points from 100 to 140 confirmed the medium level with a tendency to the low level; points under 100 meant the low level.

\section{The results of research}

We received the following data on the level of communication competence (Table 2):
Table 2. Generalized data of formation of the components of students' communicative competence (CC) according to faculties (in \%).

\begin{tabular}{|c|c|c|c|c|c|c|}
\hline $\begin{array}{c}\text { CC } \\
\text { compo- } \\
\text { nents }\end{array}$ & Faculty & \begin{tabular}{|c|} 
Al- \\
most \\
always
\end{tabular} & $\begin{array}{c}\text { In } \\
\text { most } \\
\text { cases } \\
\end{array}$ & \begin{tabular}{|c|} 
So- \\
meti- \\
mes \\
\end{tabular} & $\begin{array}{l}\text { Ra- } \\
\text { rely }\end{array}$ & $\begin{array}{c}\text { Almost } \\
\text { never }\end{array}$ \\
\hline \multirow{7}{*}{ ن. } & \begin{tabular}{|l|} 
Foreign \\
Languages
\end{tabular} & 18.2 & 33.2 & 27.2 & 19.9 & 24 \\
\hline & $\begin{array}{l}\text { Psychology } \\
\text { and Sociology }\end{array}$ & 5.6 & 46 & 16.7 & 21.7 & 20.7 \\
\hline & $\begin{array}{l}\text { Physical } \\
\text { Education }\end{array}$ & 8.5 & 38.6 & 36.4 & 13.8 & 14.7 \\
\hline & \begin{tabular}{|l|} 
Primary \\
Education \\
\end{tabular} & 0 & 42.2 & 23.3 & 37.8 & 16.7 \\
\hline & $\begin{array}{l}\text { Physics and } \\
\text { Mathematics }\end{array}$ & 10.4 & 27.4 & 30 & 22.2 & 26.3 \\
\hline & Nature & 27.3 & 28 & 28 & 20 & 23.3 \\
\hline & $\begin{array}{l}\text { Arts and } \\
\text { Graphic, Arts }\end{array}$ & 17.9 & 25.8 & 33.7 & 20 & 20.8 \\
\hline \multirow{7}{*}{ 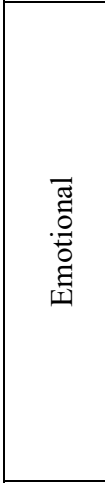 } & \begin{tabular}{|l|} 
Foreign \\
Languages \\
\end{tabular} & 15.6 & 28.1 & 24 & 23.6 & 15.8 \\
\hline & $\begin{array}{l}\text { Psychology } \\
\text { and Sociology }\end{array}$ & 11.3 & 32.7 & 24 & 32 & 14.9 \\
\hline & \begin{tabular}{|l|} 
Physical \\
Education \\
\end{tabular} & 12.6 & 29 & 30 & 17.1 & 12.6 \\
\hline & \begin{tabular}{|l|} 
Primary \\
Education
\end{tabular} & 5.56 & 48.9 & 23.3 & 20 & 34.4 \\
\hline & \begin{tabular}{|l|} 
Nature \\
\end{tabular} & 12.5 & 21.2 & 13.7 & 11.7 & 19.1 \\
\hline & \begin{tabular}{|l|} 
Physics and \\
Mathematics
\end{tabular} & 21.1 & 27.4 & 18.9 & 22.2 & 26.3 \\
\hline & $\begin{array}{l}\text { Arts and } \\
\text { Graphic, Arts }\end{array}$ & 20.4 & 38.3 & 18.7 & 21.6 & 25.8 \\
\hline \multirow{7}{*}{ 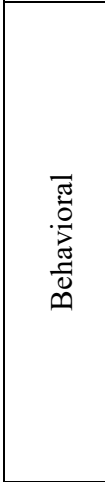 } & \begin{tabular}{|l|} 
Foreign \\
Languages \\
\end{tabular} & 32.5 & 32.9 & 21.6 & 16.5 & 14.8 \\
\hline & $\begin{array}{l}\text { Psychology } \\
\text { and Sociology }\end{array}$ & 10.4 & 33.3 & 33.5 & 21.1 & 14.8 \\
\hline & \begin{tabular}{|l|} 
Physical \\
Education \\
\end{tabular} & 19.7 & 33.3 & 35.7 & 20 & 13.1 \\
\hline & \begin{tabular}{|l|} 
Primary \\
Education
\end{tabular} & 6.6 & 40 & 43.3 & 8.9 & 16.7 \\
\hline & $\begin{array}{l}\text { Physics and } \\
\text { Mathematics }\end{array}$ & 27.8 & 29.6 & 27.8 & 8.1 & 23 \\
\hline & Nature & 20 & 34 & 22 & 18.7 & 30.7 \\
\hline & $\begin{array}{l}\text { Arts and } \\
\text { Graphic, Arts }\end{array}$ & 44.2 & 24.2 & 25 & 19.2 & 13.3 \\
\hline \multirow{7}{*}{ 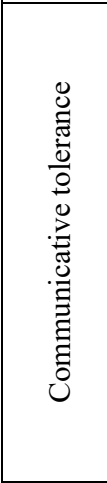 } & \begin{tabular}{|l|} 
Foreign \\
Languages
\end{tabular} & 22 & 30.7 & 28.3 & 23.02 & 16 \\
\hline & \begin{tabular}{|l|} 
Psychology \\
and Sociology
\end{tabular} & 24 & 35.9 & 27 & 16.8 & 9 \\
\hline & \begin{tabular}{|l|} 
Physical \\
Education \\
\end{tabular} & 31.9 & 36.7 & 21.4 & 12.3 & 0.48 \\
\hline & \begin{tabular}{|l|} 
Primary \\
Education
\end{tabular} & 31.1 & 13.3 & 40 & 20 & 31.1 \\
\hline & \begin{tabular}{|l|} 
Physics and \\
Mathematics \\
\end{tabular} & 27.8 & 21.5 & 21.1 & 14.8 & 17.4 \\
\hline & \begin{tabular}{|l|} 
Nature \\
\end{tabular} & 36.7 & 28 & 20 & 18.7 & 23.3 \\
\hline & $\begin{array}{l}\text { Arts and } \\
\text { Graphic, Arts }\end{array}$ & 44.6 & 26.7 & 25 & 10.8 & 15 \\
\hline
\end{tabular}

The obtained data from the questionnaire on communicative competence are presented in Table 2 and indicate that the students tried to avoid critical and negative answers, in general. They had formed CC according to all criteria and indicators but in different ways in different faculties. The results indicate the influence of the teaching profession on formation of 
communicative competence, as well as the organization of the educational process at the faculties in different ways.

According to the obtained data students have mainly formed the cognitive and emotional components of communicative competence. This is caused by lack of professional pedagogical experience and activity, that is why the behavioral component is less formed.

The students had the high level of communication tolerance because of their love for children and desire to communicate with them all as well as humanistic orientation of future teaching profession and an orientation to the acmeological approach in education (the emphasis on the highest score) as a basis for the quality of education.

The further analysis of formation of students' communicative competence was conducted with a focus on students" answers "almost always" and "in most cases" as these indicators mark the highest level of their formation and orientation to the acmeological approach in education (resistance to the highest result).

Regarding to the state of formation of the cognitive component, we should note that the Faculty of Nature took the first place; it was followed by the Faculty of Foreign Philology, the Faculty of Psychology and Sociology, the Faculty of Physical Education, the Faculty Primary Education and the Faculty of Arts; the last place is occupied by the Faculty of Physics and Mathematics. This is caused by the fact that the students of the Faculty of Foreign Philology, the Faculty of Primary Education, the Faculty of Psychology and Sociology are more likely to be taught to communicate and work with children. It is the most pronounced focus on person's professional activity, while the future teachers of Physics and Mathematics are more focused on the professional "sign to sign" activity.

In order to explain why the students of the Faculty of Nature got higher score on the cognitive component of the communicative competence, than humanitarian students, we had to talk with students and teachers of these faculties and other faculties about how they achieved such results. They explained that the faculty pays attention to the harmonious development of students' personality, that is why the psycho-pedagogical disciplines are taken as much as possible in the curriculum, they are in all of its parts, unlike other specialties at the university, where these disciplines have been significantly reduced during the recent years, and are not present at all optional blocks.

According to the emotional component of the communicative competence, students of the Faculty of Arts and Graphics took the first place, followed by students of the Faculty of Primary Education, then by the Faculty of Foreign Philology, the Faculty of Psychology and Sociology, the Faculty of Physics and Mathematics, the Faculty of Physical Education, and the last one is the Faculty of Nature.

These results can be caused by the emotionality of artistic specialties that transfer emotions from art to communication, as well as by the fact that when working with children of younger age it is impossible to work successfully without emotions, understanding, because these children are just beginning to form logical thinking, they perceive everything emotionally and figuratively. Therefore, the future teaching profession occupation as well as the age of children affect the formation of the emotional component of communicative competence.

We got average results of emotional competence of students of other specialties, particularly, students of the Faculty of Psychology and Sociology, the Faculty of Foreign Philology, the Faculty of Physics and Mathematics, the Faculty of Physical Education.

The low results of students of the Faculty of Nature indicate a lack of understanding of the significance of emotions in the pedagogical profession, life, resistance to profession and rational thinking that is insufficient when communicating with children. Comparatively, students of the Faculty of Foreign Philology and the Faculty of Arts and Graphics and Arts received the best results in the behavioral component of communicative competence. This is caused by the experience of communication of students of both faculties in a foreign multicultural environment (most of the students of these faculties were abroad, worked there, communicated with foreigners to acquire language practice, gave concerts, were on internships).

The reason for the average results of students of the Faculty of Physics and Mathematics and Nature is in their focus on the profession of "man-nature", "mansign", along with the teaching profession, which belongs to "person to person" orientation. We were surprised by low results on this component of the communicative competence in psychologists, sociologists and students of the Faculty of Primary Education.

The results of students of the Faculty of Primary Education can be caused by the fact that while communicating with young children of primary school age, students in practice do not have conflicts about the inequality of positions. The students perceived a teacher, and for this reason students do not have problems and experience in solving conflicts while communicating with children of this age, that is why their self-esteem is high. In addition, they do not have a certain language technique yet, which is formed by experienced primary school teachers: to speak briefly, little and clearly for everyone, to influence children non-verbally (because it takes into account the small amount of children's attention, their fast fatigue, rapid refocusing of attention to more interesting things, unstable attention, its spontaneity, a small amount of arbitrary attention, which is just beginning to form in children).

All above mentioned creates communicative barriers for children, leads to problems with discipline in the classroom, and students understand their problems in the behavioral component of the communicative competence after having three types of practice. Regarding to the results of the questionnaires of the students of the Faculty of Psychology and Sociology, it turned out that they deal with quite different categories of children and adults, mainly with problematic clients, so they do not have a solid experience of communication and behavior yet. 
The results of formation of the communicative tolerance were the best in students of the Faculty of Art and Graphic, Faculty of Arts, the Faculty of Physical Education, the Faculties of Nature and the Faculty of Psychology and Sociology. The students of the Faculty of Foreign Philology, the Faculty of Physics and Mathematics were separated from them. The best results are caused by the fact that students from the Faculty of Art have a figurative perception of people, all of them are beautiful, distinguished in some ways, and art requires understanding and respect.

The results of the athletes are interesting in the context of orientation towards winning in sports and tolerance in communication, which can be explained by special educational work at the faculty with future coaches and teachers of physical education (many different aged, short-term teams, team play and participation, where support and understanding are needed).

The results of psychologists and sociologists meet the requirements for the profession. The data on communicative competence of the students of the Faculty of Nature are explained by the fact that they are taught the most disciplines of the psychologicalpedagogical cycle. Also we have counted the average score of communicative competence formation (Table 3).

Table 3. Distribution of average score of communicative competence formation by faculty $(\%)$.

\begin{tabular}{|l|c|}
\hline \multicolumn{1}{|c|}{ Faculty } & Average score \\
\hline Foreign Languages & 128 \\
\hline Psychology and Sociology & 136 \\
\hline Physical Education & 132 \\
\hline Primary Education & 187 \\
\hline Physics and Mathematics & 138 \\
\hline Nature & 150 \\
\hline Arts and Graphic, Arts & 147 \\
\hline
\end{tabular}

We used the Pearson $\chi^{2}$ criterion in order to evaluate the statistical reliability of the detected values regarding the communicative competence formation. The highest level of communication competence formation was obtained on the basis of the research conducted at the students of the Faculty of Primary Education $\left.\chi^{2}=36.96\right)$ exceeds the critical value $\left(\chi^{2}{ }_{0.05}=7.815\right.$ and $\left.\chi_{0.01}^{2}=11.345\right)$. The lowest level of communication competence formation was obtained from students of the Faculty of Foreign Philology - 4.642.

The distribution of average grade point of communicative competence by faculties is represented in Figure 2.

Summarizing the results obtained by students (Table 3, Figure 1), we can say that the highest score of formation of the communicative competence was obtained by the students of the Faculty of Primary Education. They received 187 grade point, which corresponds to the average level with a tendency to the high level. At the same level, there are students of the Faculty of Nature but with fewer points (150 points) and the Faculty of Arts Graphic and the Faculty of Arts (147 points both). The received data can be explained by the fact that students of the Faculty of Primary Education have more psychological and pedagogical disciplines than students of other specialties. They study 8 methodics of teaching different subjects, which is one third of the studied subjects. More lessons are spent in practice (there are two lessons for each discipline at school, so there are 20 final lessons, while students of other faculties have only 10 final lessons). They are in the classroom during all days of practice with children and come only to their subjects. More disciplines of the humanities cycle according to the curriculum are studied by students of this faculty regarding language development (they are children's literature, the Ukrainian language, the Russian language, literature, etc.).

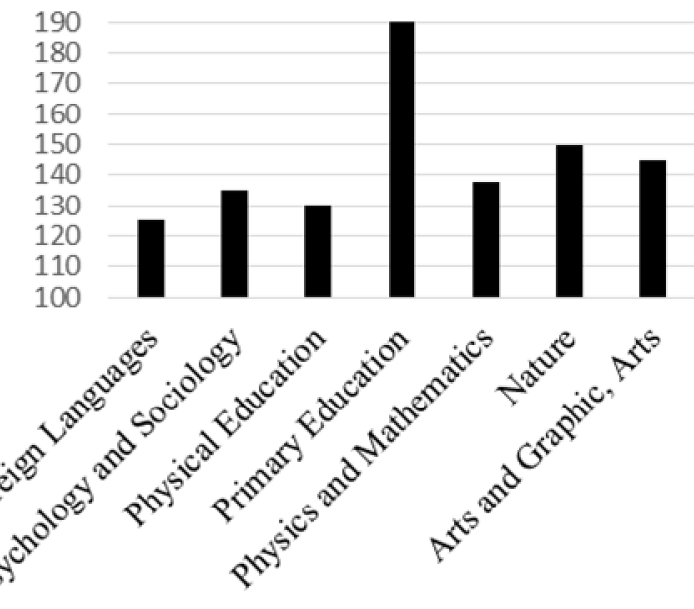

Fig. 2. Distribution of average grade point of communicative competence by faculties (\%).

The students of the Faculty of Nature are also taught a lot of methodics of teaching (botany, zoology, biology, club activities). There are more lessons given by students during the practice. The high results of students of the Faculty of Arts and Graphics and the Faculty of Arts are caused by the emotional and tolerant components, the necessity to make children and adults interested in arts, a lot of practices and exercises, which are accustomed to choreographers, singers, musicians. Therefore, when doing exercises, they fulfill pedagogical disciplines in full, which is confirmed by our experience and work with students of these specialties.

The students of the Faculty of Foreign Philology (128 points), the Faculty of Sociology and Psychology (136 points) and the Faculty of Physical Education (132 points) are almost at the same medium level. These data in the aspect of athletes, for example, correlate with our data on the average level of formation of the general competence, including communicative competences, for students of the specialty "Physical education" [15, p. 338-348]. We should note that the average level of formation of the communicative competence of students of the Faculty of Foreign Philology indicates that the study of a foreign language, even at a high level, does not provide a high level of formation of communication competence yet.

The pedagogical experiment was conducted for three years at this faculty together with the British Council. 
The issues of the experiment were the content of teaching, the training of translators and foreign language teachers. During the experiment the curriculum was reduced by $50 \%$ hours of the humanities as well as pedagogical disciplines, relatively to other faculties for studying. The study of the subject of pedagogical skills and the fundamentals of general pedagogy was replaced to pedagogical practice at school. As a result, students were at school more than students from the other faculties. However, they did not have enough theoretical knowledge of general pedagogy, pedagogical skills in sufficient quantity, which, in our opinion, was one of the reasons for the decreasing in the development of communicative competence.

These disciplines form the pedagogical skills, which include the communicative competence, give theoretical foundations for formation of it, provide exercises for development of it in the student environment. It should be noted that in general, the students of the 3-rd year of higher pedagogical educational establishment have an average level of development of communicative competence, which is sufficient level for work at school. At the same time, the reserves of formation of the communicative competence through the analysis of curricula and the obtained results were revealed: disciplines of the psychological and pedagogical cycle, a large number of methodics of teaching various subjects, a cycle of humanitarian preparation, educational work taking into account the students' specialty and their harmonious development, internship abroad, and an increased number of internships, attention to the independent professional exercise of students, who form the habit of self-working in all disciplines.

On the basis of the stated above, we distinguish the internal and external factors of formation of students' communicative competence at the higher pedagogical educational establishments. The internal factors include students' attitude to self-development, self-education, life and social experience of students, motivation to acquire a specialty and communicative competence, humanistic orientation of the future teacher', person's orientation to "person to person" profession.

The external factors include the formation of communicative competence: organization of subject leisure of students; professionally directed educational work with them; content of education in the educational institution: specialty of the chosen profession, increased cycle of humanities and psycho-pedagogical disciplines, active pedagogical practice of students; the age of the students to work with, the different categories of children and adults to communicate with. We have found out that disciplines of humanities, social and economical training, where students can spend more time discussing, proving their opinions, defend their positions, perform exercises on pedagogical communication have the greatest influence on the communicative competence development.

\section{Conclusions}

Solving the problem of imbalance between the public demand for highly qualified teaching staff and increasing the quality of general secondary education will contribute to the development of future teachers' communicative competencies. The communicative competence is considered to be a person's ability to carry out professional and further educational activities successfully as well as it is the result of training at a certain level of education, and at the same time, a teacher's professional competence. Therefore, the purpose of the article was to determine the state of formation of future teachers' communicative competence at higher pedagogical educational establishments. On the basis of determination of the level of formation of communicative competence according to the method by I. A. Martianova the following results were obtained: students of the Faculty of Primary education obtained the highest result, which corresponds to the average level with a tendency to the high level. The lowest average score was received by students of the Faculty of Foreign Philology. This proves that the presence of speech competence does not indicate the high development of communicative competence. Based on the study of formation of communicative competence through its components, it was found out that the students' behavioral component is formed at insufficient level, which can be explained by the lack of experience of professional pedagogical activity of the communicative competence. The high results of the formation showed cognitive and emotional components of communicative competence. The high level of the formation of the cognitive component of communicative competence is explained by the organization of the educational process, which is aimed more at mastering the methods of communication and teacher's work with children, students' professional orientation to people.

The emotional component of communicative competence is formed better in the students of the Faculty of Arts, which is explained by the emotionality of artistic specialties. The high level of communication tolerance of students' communicative competence is related to the humanistic orientation of the future teacher's personality. The behavioral component of the communicative competence is formed better in students of the Faculty of Foreign Philology and the Faculty of Arts. That is facilitated by the experience of communication of students of both faculties in foreign and multicultural environment. Students of the Faculty of Psychology and Sociology and the Faculty of Primary Education showed low scores on the behavioral component. The obtained results of students of the Faculty of Primary Education can be caused by the specificity of communication with young children of school age, which requires a special style of communication. Students of the Faculty of Psychology and Sociology showed such results due to the lack of practical experience with complex clients. The communicative tolerance of the communicative competence is formed better in students of the Faculty of Arts and Graphics and the Faculty of Physical Education. That is explained by the imaginative perception of students of the Faculty of Arts and Graphics and the specificity of educational work at the Faculty of Physical Education, which is focused on winning and team game. 
The obtained data can be explained by internal and external factors influencing the formation of communicative competence. The internal factors of the formation of communicative competence include students' attitude to self-development, self-education, life and social experience of students, their motivation to acquire a profession, the humanistic orientation of the future teacher's personality, the orientation of students to "person-person" profession. The external factors of the formation of communicative competence include: organization of subject leisure of students; professionally directed educational work with them; content of education in the educational institution: specialty of the chosen profession, increased cycle of humanities and psycho-pedagogical disciplines, active pedagogical practice of students; the age of children to work with, various categories of children and adults to communicate, pedagogical skill and teaching staff.

The prospects for further research are to determine the degree of influence of various factors on the development of students' communicative competence according to their chosen profession and course of study.

\section{References}

1. Pro zatverdzhenij Koncepciï rozvitku pedagogichnoiii osvity (On approval of the Concept of teacher education development) (2018), https://mon.gov.ua/ua/npa/pro-zatverdzhennyakoncepciyi-rozvitku-pedagogichnoyi-osviti. Accessed 16 July 2019

2. Pro vyschchu osvitu (About higher education) (2019), https://zakon.rada.gov.ua/laws/show/155618. Accessed 09 August 2019

3. V.G. Kremen (ed.), Rozroblennja osvitnih program. Metodichni rekomendacii (Development of educational programs. Guidelines), (Priorytety, Kyiv, 2014)

4. R. Nordquist, Communicative Competence Definition, Examples, and Glossary (2019), https:/www.thoughtco.com/what-iscommunicative-competence-1689768. Accessed 25 November 2019

5. Yu.G. Tatur, Kompetentnosnyy podkhod v opisanii rezul'tatov $i$ proyektirovanii standartov vysshego professional'nogo obrazovaniya (Competent approach in describing the results and designing standards of higher vocational education). (Issledovatel'skiy tsentr problem kachestva podgotovki spetsialistov, Moscow, 2004), http://gosvo.ru/uploadfiles/npo/20120325221547.p df. Accessed 25 August 2019

6. O. M. Tsymbalyuk, Dissertation, Rivne State Humanitarian University, 2011

7. O. V. Kasatkina, Dissertation, Vasyl Stefanyk Precarpathian National University, 2007

8. D. Hodlevska, Dissertation, National Pedagogical Dragomanov University, 2007

9. I. Romanov, Psykholohichni osoblyvosti yunats'koho viku ta yikh vplyv na formuvannya inshomovnoyi komunikatyvnoyi kompetentnosti na zanyattyakh $z$ inozemnoyi movy (Psychological peculiarities of juvenile age and their influence on the formation of foreign language communicative competence at English classes). Science And Education A New Dimension VI (164), 46-50 (2018). doi:0.31174/send-pp2018-164vi68-11

10. I. A. Zymniaia, Klyuchevyye kompetentnosti novaya paradigma rezul'tata obrazovaniya (Key competencies - a new paradigm of educational outcome). (Rossiyskiy Gosudarstvennyy Gumanitarnyy Universitet, Moscow, 2006), http://aspirant.rggu.ru/article.html?id=50758.

Accessed 25 August 2019

11. S. M. Buchachka, Komunikatyvni zdibnosti studentiv u profesiynomu spilkuvanni inozemnymy movamy (Communicative abilities of students in professional foreign languages communication). Problemi suchasnoy pedagogichnoy osviti. Ser.: Pedagogika I psihologija 1(34), 232-237 (2009), http://ibrary.vspu.net/bitstream/handle/123456789/ 1628/komunik\%20zdibn.pdf?sequence=1\&isAllowe $\mathrm{d}=\mathrm{y}$. Accessed 01 December 2019

12. I. A. Martianova, Diagnostika urovnja sformirovannosti kommunikativnoj kompetentnosti studentov vuza $v$ uslovijah polikul'turnogo obshhestva (Diagnosis of the level of formation of the communicative competence of university students in a multicultural society). Pedagogicheskie nauki 46-2 (2016)

13. Communicative Competence (2019), https://www.learnalberta.ca/content/eslapb/about_co mmunicative_competence.html. Accessed 11 December 2019

14. C.B. Paulstone, Linguistics and Communicative Competence: Topics in ESL (Multilingual Matters, Clevedon, 1992)

15. I.M. Trubavina, S.O. Vasylieva, N.O. Agarkova, in Theory and practice of introduction of competence approach to higher education in Ukraine, ed. by I.M. Trubavina, S.T. Zolotukhina (Premier Publishing, Vienna, 2019), pp. 338-347 